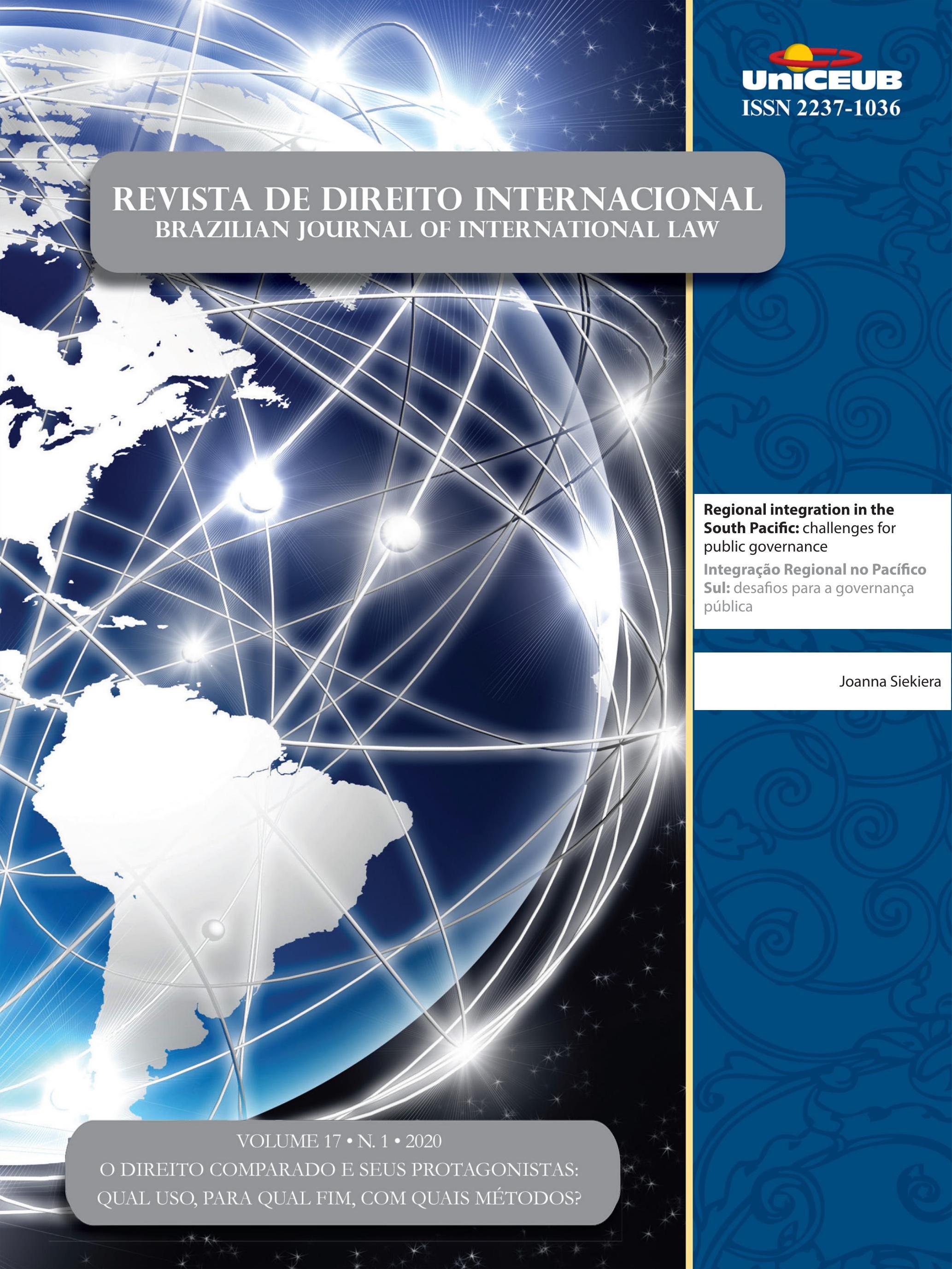


Parte I - O Direito comparado e seus Protagonistas: QuAL uso, PARA QUAL FIM, COM QUAIS MÉTODOS? .....................................................................1

EDITORIAL ............................................................................................................... 3

"Tudo o que precisamos fazer é ter certeza de que continuaremos conversando".............................. 3

Gustavo Cerqueira e Patrícia Perrone Campos Mello

Direito comparado E METOdologia $\quad$................................................... 6

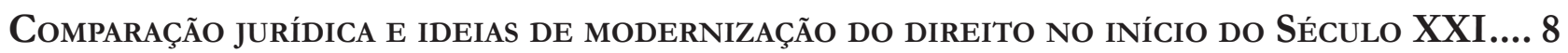
Gustavo Cerqueira

O DIREITO COMPARADO: ESFORÇO DE RESGATE HISTORIOGRÁFICO E DE PROBLEMAS METODOLÓGI$\cos$

Arnaldo Sampaio de Moraes Godoy e Gustavo Fereira Ribeiro

Direito Comparado e Política: Reflexões Necessárias .42

Raphael Carvalho de Vasconcelos e Deo Campos Dutra

Direito comparado no Brasil

L'originalité du Droit Brésilien et le Droit Comparé .57

Arnoldo Wald

LEI DA BOA RAZÃo E COMPARATISMO JURÍDICO NA DOUTRINA CIVILISTA BRASILEIRA DE 1850 A 1880

Alan Wruck Garcia Rangel

O STF EM REDE? QUANTO, COMO, COM QUE ENGAJAMENTO ARGUMENTATIVO O STF USA PRECEDENTES ESTRANGEIROS EM SUAS DECISÕES?

Patrícia Perrone Campos Mello e Felipe Meneses Graça 
Suprema Imprecisão: a metodologia em Direito Constitucional Comparado E as deficiênCias Em Seu uso pelo Supremo Tribunal Federal

Alonso Freire e Hugo Sauaia

Direitos comparados

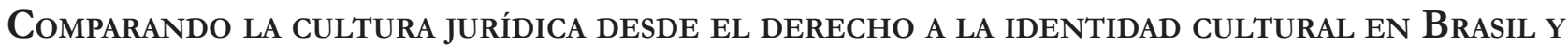

CHILE 145 Juan Jorge Faundes e Fabian Le Bonniec

O Divino e o Racional no Direito: notas para um diálogo entre sistemas jurídicos 181 Salem Hikmat Nasser e José Garcez Ghirardi

Regulação do discurso de Ódio: análise comparada em países do Sul Global 196 Jane Reis Gonçalves Pereira, Renan Medeiros de Oliveira e Carolina Saud Coutinho

Parte II - Outros temas

LA OTRA CARA DE LA MONEDA: PROTECCIÓN CONSTITUCIONAL DE LA EMPRESA, EL EMPRENDIMIENTO Y LA LIBRE COMPETENCIA EN CHILE y COLOMBiA

Juan Pablo Díaz Fuenzalida e Juan Sebastián Villamil Rodríguez

The European Court of Human Rights Decision on there 'Burqa Ban'and the CritiCal analysis of the Pragmatic experimental logic 258 Flavianne Fernanda Bitencourt Nóbrega e George Browne Rego

Direitos humanos das deslocadas ambientais e os impactos da Usina de Belo Monte: da EXPLORAÇÃO AMAZÔNICA À SUBJUGAÇÃO FEMININA

Thais Silveira Pertille e Letícia Albuquerque

Solução de Controvérsias em Acordos de Investimento: as experiênCias do CPTPP, CETA E DOS ACFIs

Fábio Morosini, Vivian Daniele Rocha Gabriel e Anastacia Costa

50 anos dos “direitos da Criança” na Convenção Americana de Direitos Humanos: a HISTÓRIA DO ARTIGO 19 311

Sven Peterke e Paloma Leite Diniz Farias 
EMPRESAS E DIREITOS HUMANOS: COMPARTILHANDO VALOR E RESPONSABILIDADES .325 Melina Girardi Fachin

CONTEMPORARY RESPONSES TO BUSINESSES' NEGATIVE HUMAN RIGHTS IMPACT 341 Andres Felipe Lopez

Human Right to LABOR PROTECTION IN UKRAINE: CURRENT SITUATION AND THE PROSPECTS OF IMPLEMENTATION OF INTERNATIONAL RULES 363 Nina Daraganova

International Regulation and Global Governance: The EU influential Method IN TIMES OF NORMATIVITY CHANGE 373 Gabriela Hühne Porto, Paula Wojcikiewicz Almeida e Juliana Maia F. A. Netto

Tecnologias digitais e o comércio de bens E SERviços na OMC/Digital. 391 Umberto Celli Junior

Los fuertes hacen lo QUe PUeden: exponiendo los límites de la Corte Penal InternaCIONAL .406

Cristián D. González-Ruiz e Víctor M. Mijares

Human Rights, Humanitarian Law and State Power 418 Renata Nagamine e João Roriz

Regional integration in the South Pacific: Challenges for Public governance .433 Joanna Siekiera

Parte III - Resenhas 443

RESENHA DA OBRA

“Democracia e policentrismo do poder", de Murilo Gaspardo 445 Angela Limongi Alvarenga Alves 


\title{
Regional integration in the South Pacific: challenges for public governance*
}

\author{
Integração Regional no Pacífico Sul: desafios \\ para a governança pública
}

Joanna Siekiera**

\begin{abstract}
The purpose of this article is to present and analyse regional integration in the South Pacific region, as well as to enumerate the potential challenges for public governance. The article is divided therefore into 5 sections, starting from introduction, where the author presents the idea of the research, gives definitions; second part deals with the South Pacific integration as an example of regionalisation, where it is necessary to present the characteristic features of the region, as well as its complex regional model of cooperation; third part enumerates obstacles for public governance gathered into categories of legal and extrajudicial challenges; forth part brings about some reason, why the Pacific microstates can be called as weak democracies; finally, fifth part forms the conclusion where the author summaries the whole research. The used methodology is the legal analysis, where the legal acts, as well as political declarations have been taken into account. Overall, regional integration in the South Pacific is weak because of a multitude of challenges for public governance. On the other hand, though, those challenges might become a motivation for the small island states to improve the level of regional governance.
\end{abstract}

Keywords: regional integration, regionalisation, Pacific, South Pacific, public governance

\section{Resumo}

O objetivo deste artigo é apresentar e analisar a integração regional na região do Pacífico Sul, bem como enumerar os desafios potenciais para a governança pública. $\mathrm{O}$ artigo está dividido em 5 seções. $\mathrm{Na}$ introdução, o autor apresenta a ideia da pesquisa com as devidas definições. A segunda parte trata da integração do Pacífico Sul como um exemplo de regionalização, onde é necessário apresentar as características da região, bem como seu complexo modelo regional de cooperação. A terceira parte enumera os obstáculos à governança pública reunidos em categorias de desafios legais e extrajudiciais. A quarta parte uma reflexão sobre a razão pela qual os microestados do Pacífico podem ser chamados de democracias fracas. Finalmente, a quinta parte apresenta-se como uma síntese de toda a pesquisa. A metodologia utilizada é a análise jurídica, na qual foram considerados os atos jurídicos e as declarações políticas. No geral, a integração regional no Pacífico Sul é fraca

** International lawyer at the University of Bergen, Norway; $\mathrm{PhD}$ at the Warsaw School of Economics, Poland; PhD scholar at the Victoria

University of Wellington, New Zealand. Email:
Recebido em 07/04/2020

Aprovado em 16/05/2020 
devido a uma infinidade de desafios para a governança pública. Por outro lado, esses desafios podem se tornar uma motivação para os pequenos Estados insulares melhorarem o nível de governança regional.

Palavras-chave: Regional integration. Regionalização. Pacífico. Sul Pacífico. Governança Pública.

\section{Introduction}

The Pacific Ocean is the largest water basin in Earth. Despite this obvious geographic fact, the region remains isolated in both terms of geopolitics and academic interests. Research on the Pacific (so-called Pacific Studies) are highly needed also in the humanities, and legal studies. The huge importance of this geopolitical region can be observed since the last decade of the $20^{\text {th }}$ century. First of all, regardless of the international legal status of the countries ${ }^{1}$ located in the Australian continent, they are all involved in the global negotiations on universal norms, mainly through the United Nations (UN). The common voice of those Pacific Small Island Developing States (PSIDS) ${ }^{2}$ became only relatively recently heard at the global arena. It appears to be common that very often in international law the regional regimes turn out to be a sufficient, less expensive and far quicker solution for the local problems or dilemmas then those at the global level'. Already now, the Pacific governments ("Pacific bloc" within the UN) engaged itself into climate change diplomacy, with considerable success. During the $13^{\text {th }}$ session of the Conference of the Parties (COP 21) in Paris, the Pacific bloc managed to convinced states to approve the agreement on keeping a global temperature rise in the $21^{\text {st }}$ century below 2 degrees Celsius above pre-industrial levels (Paris Agreement 2015) ${ }^{4}$.

\footnotetext{
Here is essential to clarify that not all of the international entities in the Pacific possess the full personality as sovereign states. There are many dependent territories, as well as free associated states, which have limited scope of autonomy in internal and external matters. That affects their extent of participation in regional cooperation. Email: joanna.axe@gmail.com

2 The author is a member of the ocean change project at the University of Bergen, entitled "Mare Nullius: Sea level rise and maritime sovereignties in the Pacific". See the brochure made for the Division for Sustainable Development Goals at the Department of Economic and Social Affairs in the UN by fellow workers: O. Goransson, M. Vierros, C. Borrevik, Partnerships for Small Island Developing States, April 2019.

3 G. Fry, S. Tarte, The New Pacific Diplomacy, Australian National University Press, Canberra 2015.

4 Paris Agreement under the United Nations Framework Conven-
}

Another international legal movement performed by PSIDS in order to help its members to command global stages is the negotiation process over the United Nations Convention on the Law of the Sea (UNCLOS) ${ }^{5}$. Here a slightly longer explanation needs to be made. Ocean change, intentionally used by the author instead of "climate change" in order to emphasise the main result of climate change to the Pacific region, is now one of the biggest threats facing humanity. It appears indisputable that changes in Earth's environmental system are already causing huge harm especially to the small coastal and island states. PSIDS are indeed in the group of the most vulnerable. Still, legal consequences of ocean change have to be beared in mind too. Potential loss of territory, and consequently sovereignty, as well as losing their exclusive economic zones (EEZ) will eventually lead to unprecedented migrations for the small island stated in the Pacific. UNCLOS was not drafted in the time when the sea level rise was just occurring, therefore the Convention lacks legal concepts for how to legally react now as the islands and their EEZs are sizing down. Process of submissions to UNCLOS in order to seek improved legal recognition of the zones, fully under the ocean change dynamics, is being held under the "Biodiversity Beyond National Jurisdiction" negotiations. The complex and highly relevant BBNJ became the topic of the international discussion, launched by PSIDS, and then the subject matter was codified in a form of the UN General Assembly Resolution in $2017^{6}$.

It should be stated already in the beginning that regional integration in the South Pacific is weak because of a multitude of challenges for public governance. On the other hand, though, those challenges might become a motivation for the small island states to improve the level of regional governance.

\section{South Pacific integration}

The region in concern is tighten up to the South $\mathrm{Pa}$ cific instead of "the Pacific". Still, the author uses the

tion on Climate Change of 22 April 2016.

5 United Nations Convention on the Law of the Sea of 10 December 1982, ratified in 1994.

6 The full title being: International legally binding instrument under the United Nations Convention on the Law of the Sea on the conservation and sustainable use of marine biological diversity of areas beyond national jurisdiction of 24 December 2017 (A/72/L.7). 
term Pacific for the Pacific island territories and countries (PICT) laying down south to the equator. Thus, "the South Pacific" is the most suitable name in order to differentiate the existence of Oceania states, which are not part of the Asian continents, as some scientists still use the term "Pacific" when referring to the insular part of East Asia?. "Oceania" in turn is not used in any normative texts; therefore, it is hard to find its definition. Still, this is how the inhabitants of the South Pacific prefer to call its home region, what in turn represents the huge cultural and biological diversity ${ }^{8}$. Oceania islanders perceive themselves as "people of the sea". This approach enables them to identify the ocean not only as their home, but also as foundation of their very existence?.

There should also be given a counterargument stating that great distances in the Pacific are in fact not an persisting problem for regional integration. It is the geographical fact that the Pacific is $10,000 \mathrm{~km}$ west to east and 5,000 km north to south. Nonetheless, slight inhabited areas and small population can make regional cooperation even more effective having in mind common purpose. Here comes the phenomenon of regional identity, which allows islanders to perceive themselves as a part of the big Pacific family. It is called "Pacific identity".

There can be observed the growing awareness of the affiliation to the region by the involvement in many intergovernmental organizations (IGO), non-governmental organizations (NGO) and other non-state institutions acting with the purpose of the Pacific integration. Those organisations and other ad hoc institutions will be briefly presented in the further part of the article. Loyalties along with the feeling of affiliation to one community, the Pacific community, is very often brought from the family and is further cultivating at the national level. Thus, islanders regard their states as the basic elements of the Pacific Community ${ }^{10}$. Participa-

There became popular another grouping of influential states from the Pacific Rim recently, under the joint name of the new North Pacific. Compare: M. Fry, J. Kirton, M. Kurosawa (ed.), The North Pacific Triangle: The United States, Japan, and Canada at Century's End, University of Toronto Press, Toronto 1998.

8 E. Hau'ofa, Our Sea of Islands. "The Contemporary Pacific", 1994/6; B.V. Lal, K. Fortune, The Pacific Islands: An Encyclopedia, University of Hawai'i Press, Honolulu 2000.

9 P. D'Arcy, The People of the Sea: Environment, Identity, and History in Oceania, University of Hawai'i Press, Honolulu 2006.

10 R. Crocombe, The South Pacific, University of the South Pacific, Suva 2001, p.591. tion and advance actions through the regional agendas bring an even stronger sense of Pacific identity, while the feeling of Pan-Pacifism grows too. This affiliation is shown in increased membership in the regional institutions, through their meetings and scholarships across the region. Therefore, one can observe in this double way process kind of "self-driven" regionalism.

Nevertheless, somewhere between the sense of national and regional identity, there is also a "subregional identity". It implies the affiliation to one of three groups of the Pacific countries. Regional identity across the Pacific may therefore form the following dimensions: Melanesian Way, Micronesian Way or Polynesian Way. More than any other part of the world, the Pacific is different in cultural matters, including languages. The Pidgin language facilitates cooperation based on Melanesian identity ${ }^{11}$. It is preferred in social gatherings, but not at the official ministerial meetings. The fragmentation of language (Creole languages) is indeed a characteristic feature in the Pacific. Nonetheless, it does not affect the cooperation process. Much of the greatest integration activities is held in English - among Commonwealth countries ${ }^{12}$. In the case of closer integration, this feeling of "Pacificness" grows and islanders are more likely to cooperate with their neighbours ${ }^{13}$. The Pacific region's strength lies thus in its multiplicity.

Regional integration is set in both regionalisation and regionalism processes ${ }^{14}$. Those two routes are undeniably connected with one another. Regionalisation refers to the process of region formation, by which regions come into existence and are consolidated as separate entities $^{15}$. Region formation has to be based on suitable ground: regional space (set on a particular territory, having own social identity), regional complex (with trans-local relations), regional society (organised in formal way), and regional community (multitude of links based

11 B. Warner, Caribbean integration - lessons for the Pacific? Development Policy Centre Discussion Paper 25, Crawford School of Public Policy, Australian National University, Canberra 2012.

12 R. Crocombe, The South Pacific: An Introduction, University of the South Pacific, Suva 1989, p. 180.

13 Ibidem, p. 178.

14 Differentiation between them was already touched upon by the author in the previous edition of "Brazilian Journal of International Law": J. Siekiera, South Pacific regionalism as a driver of environmental policy - legal approach, BJIL Vol. 16 No 2 (2019), p. 116-124.

15 B. Badie, D. Berg-Schlosser, L. Morlino (ed.), International Encyclopedia of Political Science, Vol. 2, SAGE Publications Inc., Los Angeles 2011, p. 2246. 
on shared values and goals $)^{16}$. This process might be also characterised by long-term intensification and deepening of relations, mainly economic, between subjects (states, as they set the international norms) in geographic proximity to each other. Through those economic, social, cultural and political linkages, the whole region becomes intensely correlated. Hence, one can assume regionalisation is perceived as regional cooperation de facto, while regionalism - de iure ${ }^{17}$.

It has to be added here that the author is intentionally using such differentiation, even though it does not appear as common in the literature ${ }^{18}$. Process of regional cooperation in the Pacific is multidisciplinary and varied, while not only replying on political and economic growth. It is being maintained though either formal and binding intergovernmental organizations (IGO), or less formal ways where non-governmental organization (NGO) along with other ad hoc institutions do not create any valid norm. According to the author's calculation, there are over 30 regional organizations, status of which is very often hard to find. There is also over a dozen of less formalized groupings of states. Without going into details, it can be said that even the status of the three most influential IGO in the South Pacific was and still is controversial. The Secretariat of the Pacific Community (SPC) was established in 1947 by non-Oceania states by signing of the Canberra Agreement ${ }^{19}$. The Pacific Islands Forum (PIF) was created in 1971 only with the Pacific members, while not the administering metropolitan states, just like in the case of SPC. However, its international personality was emerged only in 2000 when the Tarawa Treaty ${ }^{20}$ recognised the legal personality of the Secretariat of PIF in each of its sixteen

16 E. Stadtmüller, Regionalizm i regionalizacja jako przedmiot badań naukowych w stosunkach międzynarodowych, in: K. Jędrzejczyk-Kuliniak, L. Kwieciński, B. Michalski, E. Stadtmüller (ed.), Regionalizacja w stosunkach miedsynarodowych; Aspekty politycznogospodarcze, Wyd. Adam Marszałek, Torun 2008, p. 25-26 [Regionalisation in International Relations; Political and Economic Aspects].

17 R. Orłowska, K. Żołądkiewicz. Globalizacja i regionalizacja w gospodarcze światowej, Polskie Wydawnictwo Ekonomiczne, Warsaw 2012, p. 169-171 [Globalisation and regionalisation in the world economy]. 18 Some authors suggest the existence of de iure and de facto regionalism, which would imply the various functioning of the already set institutions and legal mechanism, among which some work only on paper (de iure), while the rest form legally binding norms. See: R. Higgott, De facto and de jure regionalism: The double discourse of regionalism in the Asia Pacific, "Global Society" Vol. 11 (1997).

19 "Canberra Agreement" - Agreement establishing the South Pacific Commission of 6 February 1947.

20 Agreement Establishing the Pacific Islands Forum Secretariat of 30 October 2000. member countries, while not PIT as such. Finally, the latest IGO in the Pacific, the Pacific Islands Development Forum (PIDF) was formally established in $2015^{21}$ after two previous informal gatherings. PIDF is $\operatorname{seen}^{22}$ as a response to over politicised PIF. Among subregional organisations, there are no IGO, but two main forums came forth. The Melanesian Spearhead Group ${ }^{23}$ and the Polynesian Leaders Group ${ }^{24}$ gather regularly to launch close cooperation in basic disciplines, like health care, judiciary, police units.

The smaller, grass rooted initiatives create, however, the potential threat of putting subregional interests over the general, regional ones. On one hand, the Pacific region's strength lies in its multiplicity. Sadly, on the other, stratification among the Pacific economies is immense and generates even more spheres of interests ${ }^{25}$. The Pacific is now at the moment of regionalisation, within the process of region development, where the separate entity is being created and becomes aware of its own uniqueness, as well as obstacles, which can be overcome by the local means and methods. Those economic, social, cultural and political linkages have, been, since the 1980s, establishing the long-term intensification, and finally erecting the term of "Pacific". Contrariwise, the South Pacific region is not yet (if ever) at the moment of regionalism. This expected and indeed desired process of region formalization is long before the small, poor and undeveloped island microstates. They do have own national barriers, including those of the legal nature, and as soon as they manage them, they will be able to build the harmonized legal order at the level of the whole region.

${ }^{21}$ Charter of the Pacific Islands Development Forum of 4 September 2015; it needs to be added that another treaty was signed but not ratified yet by the member states. Agreement Establishing the Pacific Islands Forum, done at Port Moresby on 27 October 2005 will grant legal personality for PIF.

22 S. Tarte, A New Regional Pacific Voice? An Observer's Perspective On The Pacific Islands Development Forum, Inangural Summit, Denarau, Fiji, 5-7 August 2013, "Pacific Islands Brief”, 28 August 2013.

23 Compare: https://www.msgsec.info/ (18.11.2019).

${ }^{24}$ No website exist. I. Iati, Pacific Regionalism and the Polynesian Leaders Group, “The Round Table” 2017/106(2).

25 The poorest extreme is represented by Kiribati, Solomon Islands, Tonga or Vanuatu. M. Jędrusik, Wyspy tropikalne: W poszukiwaniu dobrobytu, Wydawnictwa Uniwersytetu Warszawskiego, Warsaw 2005, p.143. 


\section{Legal and extrajudicial obstacles}

The analysed region consists of the island microstates (also called microeconomies). This implies necessity of facing some of the challenges associated with smallness, as well as remoteness. But what is more relevant is their physical separation from continental lands. There is a high dependence on sea and air transport to establish and maintain both domestic and international links. What is more, the Pacific islands have made themselves more exposed to financial flows and possible global crisis. There are not many instruments to deal with external shock, especially when microstates decide to be legally (and functionally) predicated on own independence. In addition, islands do not possess sufficient number of qualified personnel. The human resources in government, administration, education and other vital sectors are lacking. Another aspect of small population in microstates is difficulties in separating personal, political and institutional interests ${ }^{26}$. This situation appears evident in both local levels of villages, certain islands, but also at the state level.

"The Pacific Way" is a slogan emerged to promote the Pacific identity. Besides the self-promotion, the other reason was to increase the regional formation in order to create one united region. It was coined by the first Prime Minister of Fiji, Ratu Sir Kamisese Mara, in 1970. He is still perceived as the most prominent regional leader in the Pacific. His main achievement was to make Fiji the biggest beneficent from Pacific regionalism ${ }^{27}$. Nonetheless, the other important outcome of Prime Minister's regional politics was to elaborate the Pacific reputation outwards and to simulate regional identity inwards ${ }^{28}$. Development of the modern Pacific regionalism is being made mainly through signing treaties ${ }^{29}$ and establishing intergovernmental organizations $^{30}$. Contrary to well-known and primary in usage hard law methods, there are also many soft law instruments. The latter ones are more flexible, easier and de-

\footnotetext{
26 B. Warner, op. cit.

27 R. Crocombe, The South Pacific, p. 157.

28 Interviews made by the author with Prof. Tony Angelo, a constitutional lawyer at the Victoria University of Wellington (VUW) in New Zealand. He was also a supervisor of the author during her $\mathrm{PhD}$ scholarship in 2015-2016.

29 In accordance with Vienna Convention on the Law of Treaties from 22 May 1969.

30 Therefore, not every regional grouping can be called as an international organization.
}

sirable for states. Why is that? Governments of certain states might not very often have an intention to formalise and maintain definitive bilateral or multilateral relations. Through international actions, such as signing a treaty, attending at an intergovernmental conference, participating at an international organisation, or establishing diplomatic or consular relations, states impose on themselves international rights and duties. Those duties may be de iure enforced in the future.

However, the Pacific states are not always willing to accomplish those regional duties, as they already struggle with domestic problems, at the governmental scale. After two waves of decolonisation, 1962-1970 and 1974-1980, there became a new legal situation for the island states. Former colonies, of mainly Great Britain, have finally gained international sovereignty and accordingly possessed, for the first time in their nationhood history, a status of independent entities. In other words, the Pacific nations, from now on the Pacific states, were at last able to make and execute own law. Sadly, those newly established and recognises states were not (and still are not) prepared to govern in a democratic way. However, also those of the islands that were not British or French colonies had to re-create a legal system suited to the western values of a democratic rule of law. Achieving the full independence of microstates in the Pacific should be, therefore, understood as the final step in the decolonization process, which was not monolithic, but was characterized by a multitude of varieties and strategies ${ }^{31}$.

The specificity of the Pacific region, resulting from its oceanic features, has an obvious impact on the legal culture of states, as well as the laws they pass. States create their legal order consisting of norms with universal impact, both at the national and regional level. However, those two levels must be compatible with the international system, which the Pacific governments are fully responsible for. In addition, the Pacific island states possess the specific legal culture. This term should be understood as a way of understanding legal norms along with the entire system of the state's functioning, as well as choosing which values are protected, along with their impact on society and individual entities. These common normative values help the state to create a unique social order, and then an economic system

\footnotetext{
31 M. Quanchi, End of an Epoch: Towards Decolonisation and Independence in the Pacific, "Agora" 2008/43(4), p. 19.
} 
conditioning the standard of living, including expected prosperity, and ending with a sense of internal and external security.

The problems faced by the newly created countries in the South Pacific are almost identical, despite the difference in belonging to one of the three subregions. The weakness of young democracies in the South $\mathrm{Pa}$ cific comes from the fact of (too?) rapid change of administration on the islands. Such quick process of modernization was made due to the desire to exercise independence without unnecessary delays, and thus introduction of changes without any burden of their former metropolitan norms. These legal systems of European colonialists, which proved themselves in a different geographical and civilizational space, were not adopted properly in the Pacific islands. Such legal order imposed by the British, French or Americans was later called as "acquired law", "introduced law", or "received law" 32 . All those names suggest the noticeable fact that islanders themselves do not perceive democracy as something what belongs to them but they rather associate it with old, negative times of colonialism.

Taking into account the provisions of the national law of the Pacific states, along with their international declarations governments in the South Pacific are being democratically elected, and then they pursue politics using only democratic means of power. In practice, too, there is a tendency of the Pacific politicians to govern in a stable manner ${ }^{33}$. Nevertheless, de facto, the same countries appear to be defective democracies, full of legal and political contradictions, which cause suffer for their citizens, as well as whole economic and civilization development. However, the instability of the Pacific democracies is not only strictly a national threat, but also a danger to the entire Pacific region increase. It is where the interests of the global powers meet. The Pacific basin is the most extensive point of trade, primarily made by the sea but also by air. Former Australian Prime Minister Kevin Rudd, as a political excuse for his country's intervention in the affairs of microstates in the Pacific, had forged the term "arc of instability" ${ }^{4}$. This had

\footnotetext{
32 B. Hughes, Report on the South Pacific countries, "New Zealand Yearbook of International Law" 2005/2, p. 274.

33 The most glaring exceptions from this general rule were the conflict in West Papua (so-called Western Irian, former province of Indonesia) in 1950-1962, as well as modern military coups in Fiji $(1987,2000$, and 2006).

34 K. Rudd, The Mismanagement of Australia's National Security: the Death of Disarmament as a Priority of Australian Diplomacy, Address
}

an obvious connection with the so-called "Howard doctrine" - the term used in 1999, which defined the Australian regional policy starting from the cabinet of John Howard (1996-1998). This doctrine determined the need to interfere in the affairs of the region, and thus somehow gained Australia the name of a regional power or even a sheriff ${ }^{35}$.

In the vast majority of islands in the Pacific, there can be observed a lack of efficiency of the state administration bodies, which should implement reforms. Second thing is that the parliamentary structures have no real effect on pursuing laws. With regard to ineffective internal policies, it should be clarified that the primary problems appear already at the stage of suggesting reforms. A number of formal and substantive doubts can be given here. First of all, former colonies did not have legal universities, or so-called administrative and judicial staff forges for the newly created state apparatus ${ }^{36}$. The Pacific politicians, derived from the local tribes or clans, did not have any education to introduce the necessary regulations to transform own post-colonial states. In addition, technical reconstruction of the state system required establishing of the appropriate public bodies, chambers, commissions, etc. In the Pacific, such reconstruction equivalent was the institution of governors introduced by metropolises or local governments, after all, filled only with the European officials ${ }^{37}$. Hence, the newly independent Pacific states were forced to adopt the legal orders of their former administrations.

When it comes to the parliaments, which do not bring the expected legislative results, it should be stated that this is caused by two reason. First reason lays in insufficient training (or often simply the lack thereof) of public officials, which was already recalled in this article. Secondly, there is a lack of adequate organs equipped by the effective competences, including the possibility of enforcing the established earlier provisions. The $\mathrm{Pa}-$

to the Commemoration of the 10th Anniversary of the Canberra Commission, Brisbane 2.08.2006.

35 R. Leaver, The meaning, origins and implications of 'the Howard Doctrine,, “The Pacific Review” 2001/14, p. 15-34.

36 This situation remains unchanged also in the $21^{\text {st }}$ century, when the only law faculty in this enormous Pacific basin is the University of the South Pacific (USP), being a field institute in Vanuatu. There is also a tendency to send representatives of a given community or tribe to Wellington, Auckland or Sydney in order to obtain prestigious higher education. The author observed this during her doctoral scholarship at the Faculty of Law oat VUW.

37 H.N. Van Trease, The Politics of Land in Vanuatu: From Colony to Independence, Suva 1987. 
cific countries are aware of structural problems, which they are trying to solve by establishing offices aimed at controlling reforms. An example here can be the special committee of the Fiji government, which prepares legal and political assessments of the effectiveness of the introduced changes. This body watches over correctness of the smooth merging of two legal orders - local and postcolonial ${ }^{38}$. In other countries, like in Vanuatu or the Solomon Islands, the organs reforming the legal system, despite their de iure existence, de facto they did not function due to the lack of budget funds, thus producing no effects.

\section{Reason for the weak democracies}

What is very important when considering obstacles in regional integration among the developing countries to initially look at their civilization problems. Those obstacles are mainly presented in difficult or even lack of access to potable water, provision of proper health care or elementary education. Hence, the Pacific parliaments decide to allocate funds and competences of governmental or local government bodies for development aid instead of reforming the legal system. Thus, the systemic transformation did not take place entirely and successfully in the $20^{\text {th }}$ century. It, however, still does not take place in the new century, as it was expected to happen right after gaining independence. The weaknesses of democracy in Oceania are evident in the fact that neither legal norms exist in certain areas of life at all, nor residents or representatives of state authorities respect them.

Obstacles in correct implementation of democratic principles of law can be found in a variety of reasons. Among the social factors of the obstacles in performing effective national and regional policies, the most vital are cultural ones. Institutional attempts to reconcile the two legal orders: the colonial, built in most cases on the British common law system, and the local tradition of the Pacific islanders, resulted in appearance of many formal and substantive dilemmas. These problems concern political and legal spheres, and thus essential public areas relevant to the efficient functioning of a sovereign

Fiji Law Reform Commission Act of 6 April 1979. The Laws of Fiji: https://laws.gov.fj/Acts/DisplayAct/2295 (18.11.2019). $\operatorname{state}^{39}$.

Incorrect or even incomplete political transformation of the young Pacific democracies can be explained by three basic aspects. First of them is rigid, adamant bureaucracy, completely detached from any local realities. Any attempts, suggested in order to introduce innovative solutions to lead the Pacific governments out of the economic and humanitarian collapse, are being strongly refused by both public officials and ordinary residents. Those attempts are perceived as an inevitable announcement of instability in already unstable economic and social situation. Not so many interprets the reforms as being positive or even necessary to improve the living conditions of the region inhabitants. Implementation of legal mechanisms depends on activity (or rather lack of it) of public administration clerks. Hence, in the case of the Pacific democracies, one can see an open and persistent recession ${ }^{40}$.

Second feature implies the static culture being present in the traditionalist societies. In the Pacific therefore, there is a strong feeling, connotation against changing the existing status quo. Islanders, both average citizens, as well as officials and politicians, effectively oppose any introduction of changes in legislation, as well as private life norms. Everyday practices of the Pacific inhabitants are deeply rooted in their ancestors' spiritual beliefs, which all together form "the Pacific identity" ${ }^{41}$. On one hand, the feeling of the Pacific community definitely enriches the region and its societies. On the other hand, this culture and tradition appears as an obstacle that is difficult to circumvent in carrying out political reforms. The most striking examples, known and described extensively by press and literature, are the legally protected noble payments, as well as public tolerance of domestic violence ${ }^{42}$. Although the exemplifications cited here come from the Kingdom of Tonga, the same factual and legal situation prevails throughout the whole Pacific. Fortunately, this "feudal" system is being contested by the young generation pointing to its incompatibility with the principles of a democratic and egalitarian rule of law ${ }^{43}$.

\footnotetext{
39 Pacific Institute of Public Policy: http://pacificpolicy. org/2015/07/why-pacific-reformers-find-it-difficult (18.11.2019).

40 J.M. Fanelli, G. McMahon, Understanding Market Reforms: Volume 2: Motivation, Implementation and Sustainability, Springer, New York 2006, p. 230-255

41 R. Crocombe, The South Pacific, p.591

42 P. Langa'oi, The Roots of Instability: Administrative and Political Reform in Tonga, Asia Pacific University, Tokyo 2009, p. 21-35.

43 Nobles nobbled, „The Economist” (11.01.2015): http://www.
} 
Thirdly, the impact of institutionalized religion, its misinterpretation by a significant portion of the Pacific population, needs to be mentioned. Faith is the foundation of both collective and individual Pacific identity. Here, however, a clear distinction must be made between the steadfast experience of faith on one side, and the orthodox interpretation of Christian doctrine on the other. The dominant religion among the Pacific states is Christianity ${ }^{44}$. It introduced the "Sunday law" principle. Sunday law, also known as "blue law", obliges state legislators to pass provisions that prohibit conducting commercial transactions on public holidays ${ }^{45}$. This applies to not only recreational activities during Sundays and church holidays, but also to the transport sector (by sea and air) and fisheries, which are the basis of most of the Pacific economies. In the isolated and logistically undeveloped Pacific region, this aspect appears as indeed strategic. For this reason, it is impossible to close entirely airports or harbours, as the life and health of residents depend on interisland transport. In addition, public and private transport, supplies of food (including potable water) and medical products, as well as energy raw materials, due to the great distances and travel costs, take place relatively rarely ${ }^{46}$. The occurrence of a particular holiday on the day when sea or air delivery is planned might mean its suspension. This in turn results in chaos among the population and considerable disorganization of the islands ${ }^{47}$.

Finally, there are also systemic problems within the Pacific societies, which unable public governance to pass effectively any democratic reforms, but most importantly those problems unable public governance itself to function properly. The major issue is a problem of corruption, which is encountered at every level of society: from the local, rural settlements, larger population centres, through official, administrative relations, up to nationwide political ties building the island autho-

economist.com/news/asia/21638913-tonga-gets-common-manprime-minister-nobles-nobbled (18.11.2019).

44 The main denomination is Catholicism. See American agency Pew Research: http://www.pewforum.org/2012/12/18/globalreligious-landscape-christians/ (18.11.2019).

45 D.N. Laband, D.N. Heinbuch, Blue Laws: The History, Economics, and Politics of Sunday Closing Laws, Lexington Books, New York 1987. 46 Interview made by the author with Dr. Dariusz Zdziech, founder of the Australia, New Zealand and Oceania Research Association (ANZORA) and the humanitarian aid foundation "Poland helps Poland", which helps the islanders of a small village in Kiribati, which was named Poland. Cracow, 16.09.2016.

47 M. Jędrusik, op. cit., p. 101-120. rities $^{48}$. Weakness of democracies in the South Pacific states is demonstrated at the same stage by their poor ability to prosecute crime or solve social problems. In addition, law enforcement rarely reaches rural clusters living already on the edge of poverty. The main shortcoming of the Pacific state legal systems is the low expenditure on law enforcement agencies. Such low salary of public clerks creates opportunities for abuse of position, nepotism and corruption ${ }^{49}$.

\section{Final conclusions}

Regional integration in the South Pacific started in the 1980s. It has not stopped yet, as the processes of close economic and political linkages are still not fully developed and implemented to the national legal orders. The reason for that is relatively young history of the Pacific states' nationhood. After many decades of hard times of colonisation, and then equally rough period of decolonisation, challenges for public governance did not disappear. What is more, with development of transport, new technologies and ways of using land and sea resources there came forth dilemmas that are more complex. Weakness of the Pacific democracies has many roots, both legal, strictly at the political level of governing the state, as well as extrajudicial, cultural, deeply based in the society and its values. Therefore, national barriers, such as lack of educated clerks, public consent on disobedience towards codified norms, as well as unwritten principles of democratic state of law bounced back at the regional level too. Regional governance needs to be improved in order to help the Pacific islanders to get out of the humanitarian crisis. To do so, the improvement has to be accomplished at the national level by overcoming obstacles, no matter of which origin.

\section{References}

Agreement Establishing the Pacific Islands Forum Secretariat of 30 October 2000.

\footnotetext{
48 R. Nicholls, Corruption in the South Pacific: the Potential Impact of the UN Convention against Corruption on Pacific Island States, "New Zealand Yearbook of International Law" 2005/2, p. 236.

49 Rapport by Asian Development Bank-Commonwealth Secretariat, Toward a New Pacific Regionalism, Pacific Studies Series 2005, p. 24.
} 
Badie B., Berg-Schlosser D., Morlino L. (ed.), International Encyclopedia of Political Science, Vol. 2, SAGE Publications Inc., Los Angeles 2011.

Canberra Agreement - Agreement establishing the South Pacific Commission of 6 February 1947.

Charter of the Pacific Islands Development Forum of 4 September 2015.

Crocombe R., The South Pacific, University of the South Pacific, Suva 2001.

Crocombe R., The South Pacific: An Introduction, University of the South Pacific, Suva 1989.

D'Arcy P., The People of the Sea: Environment, Identity, and History in Oceania, University of Hawai'i Press, Honolulu 2006.

Fanelli J.M., McMahon G., Understanding Market Reforms: Volume 2: Motivation, Implementation and Sustainability, Springer, New York 2006.

Fry G., Tarte S., The New Pacific Diplomacy, Australian National University Press, Canberra 2015.

Fry M., Kirton J., Kurosawa M. (ed.), The North Pacific Triangle: The United States, Japan, and Canada at Century's End, University of Toronto Press, Toronto 1998.

Goransson O., Vierros M., Borrevik C., Partnerships for Small Island Developing States, Division for Sustainable Development Goals, Department of Economic and Social Affairs, UN, April 2019.

Hau'ofa E., Our Sea of Islands. "The Contemporary Pacific", 1994/6.

Higgott R., De facto and de jure regionalism: The double discourse of regionalism in the Asia Pacific, "Global Society" Vol. 11 (1997).

Hughes B., Report on the South Pacific countries, "New Zealand Yearbook of International Law" 2005/2.

Iati I., Pacific Regionalism and the Polynesian Leaders Group, “The Round Table" 2017/106(2).

International legally binding instrument under the United Nations Convention on the Law of the Sea on the conservation and sustainable use of marine biological diversity of areas beyond national jurisdiction of 24 December 2017 (A/72/L.7).

Interview made by the author with Dr. Dariusz Zdziech, Cracow, 16.09.2016.
Jędrusik M., Wyspy tropikalne: W poszukiwaniu dobrobytu, Wydawnictwa Uniwersytetu Warszawskiego, Warsaw 2005.

Jędrzejczyk-Kuliniak K., Kwieciński L., Michalski B., Stadtmüller E. (ed.), Regionalizacja w stosunkach miedsynarodowych; Aspekty polityczno-gospodarcze, Wyd. Adam Marszałek, Toruń 2008.

Laband D.N., Heinbuch D.N., Blue Laws: The History, Economics, and Politics of Sunday Closing Laws, Lexington Books, New York 1987.

Lal B.V., Fortune K., The Pacific Islands: An Encyclopedia, University of Hawai'i Press, Honolulu 2000.

Langa'oi P., The Roots of Instability: Administrative and Political Reform in Tonga, Asia Pacific University, Tokyo 2009.

Leaver R., The meaning, origins and implications of 'the Howard Doctrine', "The Pacific Review” 2001/14.

Melanesian Spearhead Group: https://www.msgsec. info/ (18.11.2019).

Nobles nobbled, „The Economist” (11.01.2015): http:// www.economist.com/news/asia/21638913-tongagets-common-man-prime-minister-nobles-nobbled (18.11.2019).

Nicholls R., Corruption in the South Pacific: the Potential Impact of the UN Convention against Corruption on Pacific Island States, "New Zealand Yearbook of International Law" $2005 / 2$

Orłowska R., Żołądkiewicz K., Globalizacja i regionalizacja w gospodarcze śniatowej, Polskie Wydawnictwo Ekonomiczne, Warsaw 2012.

Rapport by Asian Development Bank-Commonwealth Secretariat, Toward a New Pacific Regionalism, Pacific Studies Series 2005.

Paris Agreement under the United Nations Framework Convention on Climate Change of 22 April 2016.

Pacific Institute of Public Policy: http://pacificpolicy. org/2015/07/why-pacific-reformers-find-it-difficult (18.11.2019).

Pew Research: http:/ /www.pewforum.org/2012/12/18/ global-religious-landscape-christians/ (18.11.2019).

Rudd K., The Mismanagement of Australia's National Security: the Death of Disarmament as a Priority of Australian Diplomacy, Address to the Commemoration of the 10th Anniversary of the Canberra Commission, Brisbane 2.08.2006. 
Quanchi M., End of an Epoch: Towards Decolonisation and Independence in the Pacific, "Agora" 2008/43(4).

Siekiera J., South Pacific regionalism as a driver of environmental policy - legal approach, BJIL Vol. 16 No 2 (2019).

Tarte S., A New Regional Pacific Voice? An Observer's Perspective On The Pacific Islands Development Forum, Inangural Summit, Denarau, Fiji, 5-7 August 2013, "Pacific Islands Brief", 28 August 2013.

The Laws of Fiji: https://laws.gov.fj/Acts/DisplayAct/2295 (18.11.2019).

United Nations Convention on the Law of the Sea (UNCLOS) of 10 December 1982.

Van Trease H.N., The Politics of Land in Vanuatu: From Colony to Independence, Suva 1987.

Warner B., Caribbean integration - lessons for the Pacific? Development Policy Centre Discussion Paper 25, Crawford School of Public Policy, Australian National University, Canberra 2012. 
Para publicar na Revista de Direito Internacional, acesse o endereço eletrônico www.rdi.uniceub.br ou www.brazilianjournal.org.

Observe as normas de publicação, para facilitar e agilizar o trabalho de edição. 